\title{
FALling Through Statutory GaPs: CAN INDiANa Protect ENDANGERED SPECIES Without THE FEDERAL ENDANGERED SPECIES ACT?
}

\author{
R. SHANE KELLY*
}

\section{INTRODUCTION}

The federal Endangered Species Act (ESA) attempts to protect over 1,600 species from extinction. ${ }^{1}$ With help from the ESA's protections, one such species was brought back from the brink: the bald eagle. ${ }^{2}$ Although our national symbol is no longer in danger of extinction, only about two dozen of the 1,600 species have similar success stories. ${ }^{3}$ Various challenges face endangered species legislation at the federal and state levels. Congress, however, declared that it is the "policy of Congress that all Federal departments and agencies shall seek to conserve endangered species." ${ }^{\prime 4}$ Upon signing the Act, President Nixon himself stated that " $[\mathrm{n}]$ othing is more priceless and more worthy of preservation than the rich array of animal life with which our country has been blessed." "For decades past and likely beyond, it has therefore been a national goal to create effective legislation that protects our endangered species.

On August 12, 2019, the U.S. Fish and Wildlife Service (FWS) announced finalized changes to the administrative implementation of the landmark ESA, ${ }^{6}$ the first of which was made effective on September 26, 2019. ${ }^{7}$ The FWS maintained that the changes are minor and will have little effect on the federal regulations

* J.D. Candidate, 2022, Indiana University Robert H. McKinney School of Law; B.A. 2009, Ball State University - Muncie, Indiana. I thank the cited law review authors for their excellent work which allows me to continue the conversation. Most importantly, I thank my lovely wife for her support, encouragement, and heroic patience.

1. Robert L. Fischman et al., State Imperiled Species Legislation, 48 EnVTL. L. 81, 86 (2018) [hereinafter Fischman et al., Species Legislation].

2. See Jason Totoiu, Building a Better State Endangered Species Act: An Integrated Approach Toward Recovery, 40 EnVtL. L. ReP. News \& ANAlysis 10299 (2010).

3. See id.

4. 16 U.S.C.A. $\S 1531$ (West 2019).

5. Daniel Fors, Note, The Native Species Protection Act: A Deceptively-Named Measure to Destroy the Endangered Species Act, 29 VILL. ENVTL. L.J. 177, 177 (2018).

6. ESA Implementation |Regulation Revisions, U.S. FISH \& WILDLIFE SERV.: ENDANGERED SPECIES, https://www.fws.gov/endangered/improving_ESA/regulation-revisions.html (last updated Sept. 25, 2019) [https://perma.cc/GT6G-PBVR]; see also Press Release, Trump Administration Improves the Implementing Regulations of the Endangered Species Act, U.S. FISH \& WILDLIFE SERV. (Aug. 12, 2019), https://www.fws.gov/news/ShowNews.cfm?ref=trump-administrationimproves-the-implementing-regulations-of-the-\&_ID=36443 [https://perma.cc/5LQ7-4L46] [hereinafter Press Release, Implementing Regulations].

7. 50 C.F.R $\S \S 17.11,402.16-.17,424.11-.12$ (2019) ( $\S ~ 402.16-.17$ delayed until Oct. 28, 2019). 
that protect endangered species. ${ }^{8}$ However, environmentalists are concerned that the changes will have a negative influence on protections afforded to our threatened and endangered species. ${ }^{9}$

Proponents of the ESA-including lawmakers, conservation groups, and wildlife scientists - believe the changes "weaken the amount of protection received by threatened species and make it easier to remove a species from the more restrictive endangered species list." 10 There is also concern that the government will have to perform an economic impact assessment when determining whether a species can receive protection under the Act, which would be a significant hurdle for some species. ${ }^{11}$ Their biggest fear is that these so-called minor tweaks and implementation changes will be used to exploit or circumvent the ESA's protections to the benefit of industrialists and property owners. ${ }^{12}$ If the ESA is in fact weakened, or has any substantial change, more responsibility may fall to states and their respective laws for the protection of endangered species. ${ }^{13}$

The Indiana Code devotes a chapter to the protection of endangered species: the Nongame and Endangered Species Conservation Act of 1973 (NESCA). ${ }^{14}$ NESCA commands the Indiana Division of Fish \& Wildlife (INDFW) to "manage and conserve nongame and endangered species." 15 Indiana's Department of Natural Resources currently lists about 290 animal species and 600 plants on their Endangered and Special Concern Species List. ${ }^{16}$ Indiana's statutory protection also extends to and includes species listed on the ESA's threatened and endangered lists, including twenty-seven Indiana-native plant and animal species. ${ }^{17}$

There are some significant differences between Indiana and federal

8. See generally Lisa Friedman, U.S. Significantly Weakens Endangered Species Act, N.Y. TimeS (Aug. 12, 2019), https://www.nytimes.com/2019/08/12/climate/endangered-species-actchanges.html [https://perma.cc/RL3U-MJVQ].

9. See id.; see also Darryl Fears, Endangered Species Act Stripped of Key Provisions in Trump Administration Proposal, WASH. Post (July 19, 2018), https://www.washingtonpost.com/ news/animalia/wp/2018/07/19/endangered-species-act-stripped-of-key-provisions-in-trumpadministration-proposal/?noredirect=on [https://perma.cc/MJL6-PGC9]; Enrique Saenz, Endangered Species Act Revisions Weaken Protections for Animals, Plants Facing Extinction, Ind. EnVTL. ReP. (Aug. 22, 2019), https://indianaenvironmentalreporter.org/posts/ endangered-species-act-revisionsweaken-protections-for-animals-plants-facing-extinction [https://perma.cc/DKB6-C3X6].

10. Saenz, supra note 9.

11. See Friedman, supra note 8.

12. See Fears, supra note 9; see also Saenz, supra note 9.

13. Saenz, supra note 9.

14. IND. CoDE $\S \S 14-22-34-1$ to -21 (2019).

15. Indiana Endangered Species, IND. DEP'T NAT. RES. https://www.in.gov/dnr/fishwild/ 7662.htm (last visited Sept. 13, 2019) [https://perma.cc/HFM8-YEVJ].

16. Saenz, supra note 9.

17. Listed Species Believed to or Known to Occur in Indiana, U.S. FISH \& WILDLIFE SERV.: Envtl. Conservation OnLINE Sys., https://ecos.fws.gov/ecp0/reports/species-listed-by-statereport?state $=I N \&$ status $=$ listed (last visited Aug. 29, 2019) [https://perma.cc/QR5E-5HZ9]. 
protection, both statutory and regulatory. Indiana does not maintain lists of "threatened" species but has an administrative "special concern" status that offers no explicit protection. ${ }^{18}$ While Indiana recognizes and protects species listed as "threatened" by the ESA, federal delisting would automatically remove that species from Indiana protection. ${ }^{19}$ Permits for coal mining and other industries typically use federal statutory requirements like the ESA instead of separate Indiana requirements ${ }^{20}$; changes to the ESA could affect the strength of permits in Indiana. It has also been suggested that Indiana lacks adequate statutory authority to implement plans for species recovery. ${ }^{21}$ These sorts of issues, and others more subtle, may need to be addressed in the face of reduced federal regulation. If state legislation is already weaker than the ESA, then Indiana may find itself ill-prepared for even minor reductions in federal protection.

The focus of this Note is to examine the current level of protection for endangered species in Indiana through relevant statutes and existing legal research, then identify any gaps that exist. This Note will give an overview of the current federal ESA in Section I for comparison to the enacted federal changes and Indiana endangered species law. Section II will examine Indiana's endangered species legislation, the key differences with the federal ESA, and the potential impact of the August ESA changes - or even future changes - upon Indiana.

Thereafter, Section III proposes how to resolve the gaps that exist between federal and state endangered species legislation in Indiana. This proposal will discuss common weaknesses shared among state endangered species legislation as well as Indiana's greatest potential weakness when compared to the federal ESA and other states. Then, a three-pronged solution is offered in response to Indiana's weaknesses. The proposal will focus on three key areas of legislation: (1) the statutory procedures for "listing" and the categories of "endangered" and "threatened"; (2) the concept of "critical habitat" and statutory habitat protection; and (3) the final, overarching concept of "recovery planning," which seeks to promote species recovery through active management of endangered or threatened species populations, critical habitat, and adverse actions against both.

To address gaps in protection for endangered species, this Note recommends that Indiana add express legislation in three areas: (1) add a "threatened" listing to the existing "endangered" listing category; (2) strengthen protection of endangered species by requiring the designation of "critical habitat"; and (3) mandate the establishment of and adherence to "recovery plans."

18. Indiana Endangered Species, supra note 15.

19. Saenz, supra note 9.

20. IND. CODE $\S 14-34-3-14$ (2019).

21. Alejandro E. Camacho et al., Assessing State Laws and Resources for Endangered Species Protection, 47 ENVTL. L. ReP. NEWS \& ANALYSIS 10837, 10842 (2017). 


\section{THE FEDERAL ENDANGERED SPECIES ACT OF $1973^{22}$}

The passage of the ESA represented the "culmination of over seventy years of incremental federal wildlife law." ${ }^{23}$ It was a congressional pronouncement that the preservation of endangered species was an important issue for the federal government. ${ }^{24}$ The ESA has been the subject of controversy since its inception. ${ }^{25}$ Environmentalists believe it does "too little for too few species, while their opponents claim it provides too much protection for too many." ${ }^{26}$ Proponents of conservation clash with big industry "over the costs and benefits of species preservation." ${ }^{27}$ Amendments and rules updates have reshaped both the authority and administration of the ESA since its passage, but the latest changes are believed to represent a significant shift in policy. ${ }^{28}$

Since its enactment in 1973, the ESA has fully recovered "less than two dozen species . . . and hundreds have sadly gone extinct while awaiting federal listing." ${ }^{29}$ Regardless of politics or personal measure of success, the ESA does not have a track record of success for its central goal of "bring[ing] any endangered species or threatened species to the point at which the measures provided pursuant to this chapter are no longer necessary." ${ }^{30}$ This may not be a failing of the legislation itself, but instead limitations on implementation and funding. ${ }^{31}$ Some also argue that the very act of passing the legislation itself is important, as it makes preserving endangered species a goal of national importance. ${ }^{32}$

\section{A. Overview of ESA Protections and Impact}

The purpose of the ESA is to provide for the conservation of endangered and threatened species and their ecosystems. ${ }^{33}$ It binds "all Federal departments and agencies" in the effort to conserve endangered and threatened species and demands their support in furtherance of the ESA's goals. ${ }^{34}$ The fifteen sections

22. Endangered Species Act of 1973, Pub. L. No. 93-205, 87 Stat. 884 (1973).

23. Davina Kari Kaile, Note, Evolution of Wildlife Legislation in the United States: An Analysis of the Legal Efforts to Protect Endangered Species and the Prospects for the Future, 5 GEO. INT'L ENVTL. L. REV. 441, 454 (1993).

24. Id.

25. See Fischman et al., Species Legislation, supra note 1, at 82.

26. Holly Doremus, Listing Decisions Under the Endangered Species Act: Why Better Science Isn't Always Better Policy, 75 WASH. U. L.Q. 1029, 1032 (1997).

27. Kaile, supra note 23, at 477.

28. See Friedman, supra note 8.

29. Totoiu, supra note 2, at 10300.

30. 16 U.S.C.A. § 1532(3) (West 2019).

31. See Robert L. Fischman, Predictions and Prescriptions for the Endangered Species Act, 34 EnvtL. L. 451, 471-81 (2004) [hereinafter Fischman, Predictions and Prescriptions]; see also Kaile, supra note 23 , at 463.

32. Kaile, supra note 23 , at 461.

33. 16 U.S.C.A. $\S 1531$.

34. Id. $\S 1531(\mathrm{c})(1)$. 
of the Act outline and establish how endangered species are identified and protected from private and governmental intrusion. ${ }^{35}$

The ESA is known as the "pit bull" of environmental acts for its ability to successfully defend direct attacks. ${ }^{36}$ The "teeth" of the Act are its "take" provisions (discussed more in depth infra Section I.A.2), which are possibly "the most straightforward and powerful of the statutory protections for animals. ${ }^{" 37}$ It combines a variety of strategies common to progressive environmental protection law that allows for adaptation and flexible administration without statutory revision. ${ }^{38}$ There are certainly flaws and mixed results considering the overall success of the $\mathrm{ESA}^{39}$; however, such discussion is beyond the scope of this analysis.

1. Listing Species as Endangered and Interagency Consultation.-The true beginning of the endangered species protection process is "listing," considered the "cornerstone of the ESA." 40 To provide protection, the ESA first establishes how to distinguish whether a species is endangered, and the threshold requirements to qualify for listing. ${ }^{41}$ The ESA directs the Secretary of the Interior (Secretary) — which is further delegated to the $\mathrm{FWS}^{42}$ - to maintain "a formal list of endangered and threatened species." " $"$ "Threatened" is a separate category that purports to expand ESA protection to account for species that are "likely to become an endangered species within the foreseeable future." 44 In doing so, the ESA effectively broadens its coverage. ${ }^{45}$

16 U.S.C. § 1533 establishes the listing determination for endangered species. ${ }^{46}$ To create an endangered or threatened listing, the FWS may consider a list of factors including, inter alia, present or threatened habitat destruction and overutilization for commercial purposes. ${ }^{47}$ Listing determinations must be made "solely on the basis of the best scientific and commercial data available." 48 Furthermore, at least once every five years, the FWS must conduct a review of the lists to determine whether a species should be removed or its status changed. ${ }^{49}$

35. See Kaile, supra note 23, at 454-55.

36. Fors, supra note 5, at 177.

37. Paul Boudreaux, Understanding "Take” in the Endangered Species Act, 34 ARIZ. ST. L.J. 733, 733, 750 (2002).

38. Fischman, Predictions and Prescriptions, supra note 31, at 455, 459, 465-66.

39. Kaile, supra note 23, at 454.

40. Totoiu, supra note 2, at 10302.

41. 16 U.S.C.A. $\S 1533$ (West 2019).

42. Overview, U.S. Fish \& Wildlife Serv.: Endangered Species, https://www.fws.gov/ endangered/about/index.html (last visited Nov. 3, 2019) [https://perma.cc/6HLQ-BWRY].

43. Doremus, supra note 26, at 1049.

44. 16 U.S.C.A. $§ 1532(20)$.

45. See Totoiu, supra note 2 , at 10311.

46. 16 U.S.C.A. $\S 1533$.

47. Id. $\S 1533(\mathrm{a})(1)$.

48. Id. $\S 1533(\mathrm{~b})$.

49. Id. $\S 1533(\mathrm{c})(2)$. 
After listing status, the ESA includes several important safeguards. ${ }^{50}$ One is interagency cooperation, which ensures that any federal agency's actions are "not likely to jeopardize the continued existence" of endangered species. ${ }^{51}$ The consultation requirement is an essential function of the ESA, ${ }^{52}$ although beyond the scope of the analysis presented here. In brief, it purports to ensure federal agencies act with the same purpose and consider the impact of their actions upon endangered species. ${ }^{53}$ Federal agencies are typically required to consult the FWS or the Secretary if their actions meet threshold requirements regarding their potential impact on affected listed species. ${ }^{54}$

2. "Take" and Definitions of Harm.- -Another important safeguard in the ESA is the extensive list of prohibited acts for citizens regarding actions that might affect endangered or threatened species. "Take" prohibitions make the ESA one of the strongest federal environmental laws. ${ }^{56}$ The scope of the prohibitions is broad: any person of any state, any private entity like a corporation, or any public entity like a governmental agency is prohibited by the "take" prohibitions of the ESA. ${ }^{57}$ People who are "found liable of committing a 'take' face criminal or civil penalties." 58

Another critical aspect of "take" is agency interpretation of its definition and impact. ${ }^{59}$ The FWS interprets "take" to include action "which actually kills or injures wildlife." ${ }^{\prime \prime 0}$ This can include "significant habitat modification or degradation" and "significantly impairing essential behavioral patterns, including breeding, feeding, or sheltering." ${ }^{\prime 1}$ "Take" prohibitions even extend beyond critical habitat and include unprotected habitat where endangered species are found. ${ }^{62}$ There are, however, permits that authorize "take." Permits are available "if such taking is incidental to, and not the purpose of, the carrying out of an otherwise lawful activity." ${ }^{63}$ The full implications of "take" are far-reaching and often critical to endangered species legislation. ${ }^{64}$

3. Critical Habitat, Recovery Planning, and State Cooperation.-The

50. Doremus, supra note 26, at 1049.

51. 16 U.S.C.A. $\S 1536$.

52. Fischman, Predictions and Prescriptions, supra note 31, at 455.

53. Fischman et al., Species Legislation, supra note 1, at 90.

54. Id.

55. 16 U.S.C.A. $\S 1538$.

56. Boudreaux, supra note 37 , at 733 .

57. Steven G. Davison, The Aftermath of Sweet Home Chapter: Modification of Wildlife Habitat as a Prohibited Taking in Violation of the Endangered Species Act, 27 WM. \& MARY ENVTL. L. \& POL'y REV. 541, 544 (2003).

58. Totoiu, supra note 2, at 10303.

59. See Fischman et al., Species Legislation, supra note 1, at 108.

60. Id. at 91 .

61. Id.

62. See Davison, supra note 57 , at 548 .

63. 16 U.S.C.A. $§ 1539(a)(1)(B)$ (West 2019).

64. See Boudreaux, supra note 37. 
concept of "critical habitat" is also an essential feature of the ESA. Identification of "critical habitat" is crucial to protection of species and must be delineated on a map. ${ }^{65}$ Critical habitat includes geographical areas essential to the conservation of the species that require management. ${ }^{66}$ These designations are made when a listing is determined and must be the "maximum extent prudent and determinable." ${ }^{\prime 67}$ Like listing determinations, "critical habitat" must be identified "solely on the basis of the best scientific and commercial data available." 68

The establishment of "critical habitat" comes with various limitations and cannot include an entire range. ${ }^{69}$ Significantly, the FWS must "tak[e] into consideration the economic impact" of the designation. ${ }^{70}$ Thus, although the designation of "critical habitat" is required and "critical" to the conservation of endangered species, it is not as broad or powerful as "take" prohibitions. ${ }^{71}$ This is in spite of the common assertion that habitat loss from development and fragmentation are major contributors to the endangerment and extinction of species. $^{72}$

The ESA not only seeks the prevention of extinction but also the "recovery" of species. Recovery essentially means "increasing the population of the listed species" enough that it no longer needs protection and can be successfully delisted. $^{73}$ The Secretary must develop and implement "recovery plans" for every listed species, which must include specific management actions with observable, measurable criteria and estimates of time and cost. ${ }^{74}$ The Secretary must also report on those plans every two years. ${ }^{75}$ Despite this, agencies have wide discretion and "recovery plans" have no "force of law." extinction while awaiting listing is common. ${ }^{77}$ Although seemingly essential for the ESA's goal, recovery planning is not nearly as comprehensive and effective as other provisions of the ESA. ${ }^{78}$

Altogether, the comprehensive federal ESA involves a multi-faceted approach to species conservation. Some key parts of the Act, like "listing" determinations and "take" prohibitions, are detailed and have significant force of

65. Totoiu, supra note 2, at 10302.

66. 16 U.S.C.A. $\S 1532(5)$.

67. Id. $\S 1533(\mathrm{a})(3)$.

68. Id. $\S 1533(\mathrm{~b})(1)-(2)$.

69. Id. $\S \S 1532(5), 1533(\mathrm{c})$.

70. Id. $\S 1533(\mathrm{~b})(2)$.

71. See e.g., Totoiu, supra note 2 , at 10309-10. HCP means "habitat conservation plan," a document required after the designation of critical habitat.

72. Id. at 10301 .

73. Davison, supra note 57, at 542.

74. 16 U.S.C.A. $\S 1533(\mathrm{f})(1)$.

75. Id. § 1533(f)(3).

76. Totoiu, supra note 2 , at 10302 .

77. See id. at 10300 .

78. Id. at 10308 . 
law. ${ }^{79}$ Others, like "critical habitat" designations and "recovery planning," provide some statutory power for endangered species protection but not nearly enough. ${ }^{80}$ Therefore, some sections of the ESA have "teeth" that lead to its designation as the "pit bull" of environmental statutes, ${ }^{81}$ while some sections need further refinement or additional support to provide the complete protection sought by Congress. ${ }^{82}$

\section{B. The Administrative Changes of August 12, 2019}

In August 2019, the FWS announced changes to "modernize" the implementation of the ESA. ${ }^{83}$ These changes were finalized on August 12, 2019, and have already taken effect. ${ }^{84}$ The changes were technical adjustments to administrative rules, standards, and guidelines. ${ }^{85}$ However, subtle changes to rules - even the removal or addition of a single word - can potentially have a drastic impact on how the rule operates and its corresponding effect.

The changes affect three sections of ESA implementation: (1) interagency consultation; (2) listing standards; and (3) threatened species protection. The FWS changed the parameters that determine when other agencies must consult with the FWS to "ensure their actions do not jeopardize the continued existence of listed species, or destroy or adversely modify critical habitat." ${ }^{" 86}$ The FWS also changed the standards for listings, delistings, and designating critical habitat, effective September 26, 2019. ${ }^{87}$ The FWS further removed a blanket rule that "automatically conveys the same protections for threatened species as for endangered species." ${ }^{" 88}$

Opponents of the ESA, as well as entities like the Property and Environment Research Center (PERC) and Interior Deputy Secretary David Bernhardt, downplay the impact of the changes and suggest they are "codifying longstanding policies, [and] making minor technical tweaks." 89 The more significant substantive changes, according to PERC and Bernhardt, are regarded as beneficial

79. See id. at 10303.

80. See id. at 10308-09.

81. Boudreaux, supra note 37 , at 733,750 .

82. See Davison, supra note 57, at 542-43.

83. Press Release, Implementing Regulations, supra note 6.

84. Id.; 50 C.F.R. $\S \S 17,402,424$ (2019).

85. See ESA Implementation $\mid$ Regulation Revisions, supra note 6.

86. Id.

87. Endangered and Threatened Wildlife and Plants; Regulations for Listing Species and Designating Critical Habitat, 84 Fed. Reg. 45020 (Sept. 26, 2019) (to be codified at 50 C.F.R. 424).

88. Id.

89. See Press Release, Implementing Regulations, supra note 6; compare Jonathan Wood, The New Endangered Species Act Rules, Explained, Prop. EnV't Res. Ctr. (Aug. 14, 2019), https://www.perc.org/2019/08/14/the-new-endangered-species-act-rules-explained [https://perma.cc/K99F-S5YZ], with Friedman, supra note 8. 
to the implementation of the Act for the benefit of endangered species. ${ }^{90}$ Some see the ESA as unwieldy and unable to achieve its purpose, and believe the proposed changes are the beginning of a quiet overhaul to "improve" the success of the Act and its purported protections. ${ }^{91}$

Environmentalists and other proponents of the ESA - including lawmakers, conservation groups, and wildlife scientists - believe our most effective environmental law is being weakened or even destroyed..$^{92}$ There are three major concerns voiced by these groups: (1) changing listing standards and removing threatened listing protections drives extinction; (2) reemphasizing economic factors for listing will make it more difficult to list and protect critical habitat; and (3) these changes, however minor, will provide the means for industries to exploit the land, including critical habitat, where they were once prohibited. ${ }^{93}$

Threatened species once received the same protections as endangered species, despite their lesser status. ${ }^{94}$ Not surprisingly, the removal of this blanket rule caused concern because " $[t]$ he changes weaken the amount of protection received by threatened species and make it easier to remove a species from the more restrictive endangered species list." ${ }^{95}$ Eliminating the blanket protection for threatened species could drive further extinction and leave gaps that most states cannot fill, as they have relied upon the same level of protection given to endangered species. ${ }^{96}$ It is reasonable to predict that at least some threatened species will be affected by this change. What is especially concerning is that we cannot project what or when the effects will happen, as gaps may now exist across the states' endangered species laws that relied on threatened species receiving such blanket protection.

There is concern that the government will also have to perform an economic impact assessment when determining whether a species can receive protection under the ESA, which could be a significant hurdle for some species. ${ }^{97}$ As discussed earlier, the ESA requires listing determinations be based solely on scientific or commercial data. ${ }^{98}$ Previously, the FWS regulations also required listing determinations be made "without reference to possible economic or other impacts of such determination"; however, part of the August rules deletes this requirement. ${ }^{99}$ This "economic impact assessment" may allow the determination that a species is too costly to save and allow further development in critical

90. See Press Release, Implementing Regulations, supra note 6; see also Wood, supra note 89.

91. See Fears, supra note 9; see also Wood, supra note 89; Press Release, Implementing Regulations, supra note 6.

92. Saenz, supra note 9.

93. See supra notes 8-9.

94. ESA Implementation $\mid$ Regulation Revisions, supra note 6.

95. Saenz, supra note 9.

96. Friedman, supra note 8.

97. See Fears, supra note 9; see also Saenz, supra note 9.

98. 16 U.S.C.A. $§ 1533($ b)(1)-(2) (West 2019).

99. Wood, supra note 89. 
habitat. $^{100}$

The biggest fear is that these "minor tweaks" and implementation changes will be used to exploit or circumvent the ESA's protections to the benefit of industrialists and property owners. ${ }^{101}$ Relaxed interagency standards may allow industries to encroach on critical habitat. ${ }^{102}$ As habitat loss is already the major contributor to species decline, ${ }^{103}$ it is clear why this is a particularly strong source of concern.

Minor changes can have great impact. Much of the concern, however, is not about the changes themselves, but what they signal and how they are used. ${ }^{104}$ Many are concerned about the political implications of the changes and wonder if the current administration is still devoted to the conservation of endangered species, or if it is now open season on the ESA. ${ }^{105}$ Most importantly, the concern is whether political opponents of the ESA will use whatever perceived momentum generated by these changes to lobby for statutory changes that expressly weaken the ESA. ${ }^{106}$

If the ESA is in fact weakened, or has any substantial change, more responsibility may fall to states and their respective laws for endangered species. ${ }^{107}$ When federal protections are weakened, states must act locally to protect vulnerable species. ${ }^{108}$ This will be the focus of the analysis going forward: in the absence of federal protection, what level of statutory protection does Indiana provide for endangered species within its jurisdiction? Does Indiana's statutory protection work on its own, or is it lacking in key areas? And finally, what can Indiana's legislature do to address the gaps that exist in the absence of federal protection?

\section{INDIANA'S ENDANGERED SPECIES ACT ${ }^{109}$}

Indiana's NESCA requires the INDFW to "manage and conserve nongame and endangered species." 110 A nongame species is any wild animal "not hunted or trapped for sport or commercial use."111 The Nongame Wildlife Fund was established in 1982 to provide funding for NESCA. ${ }^{112}$ Indiana also receives reimbursement funds through the State Wildlife Grants program administered by

100. Saenz, supra note 9.

101. Id.; Wood, supra note 89.

102. Fears, supra note 9.

103. Totoiu, supra note 2, at 10301.

104. Friedman, supra note 8.

105. Fears, supra note 9.

106. Id.; see also Friedman, supra note 8.

107. See Saenz, supra note 9.

108. Id.

109. IND. CODE $\S \S 14-22-34-1$ to -21 (2019).

110. Indiana Endangered Species, supra note 15.

111. Id.

112. Id. 
the FWS. ${ }^{13}$ These funds go toward "projects involving species of greatest conservation need identified by Indiana's State Wildlife Action Plan." 114

\section{A. The Nongame and Endangered Species Conservation Act (NESCA)}

Indiana defines an endangered species as "wildlife whose prospects of survival or recruitment within Indiana are in jeopardy or are likely within the foreseeable future to become so." ${ }^{115}$ It also includes species listed on ESA lists. ${ }^{116}$ Species are only listed by Indiana if not appearing on the federal list. ${ }^{117}$ Therefore, if an ESA species is delisted, it will have to go through the Indiana listing process to receive protection under NESCA. ${ }^{118}$

The listing procedure in Indiana is carried out by the INDFW. ${ }^{119}$ The director of the INDFW must conduct investigations to determine whether a species needs management. ${ }^{120}$ Then, the director adopts rules to create the listing, including "management programs designed to ensure the continued ability of [the species] to perpetuate themselves successfully." 21 Review of endangered listings is required every two years. ${ }^{122}$

Management of endangered species is defined as applying data to increase a species' population to optimum levels. ${ }^{123}$ The mandate for management is somewhat vague and limited, as the only direction is to establish programs "necessary for the management of nongame species." 124 Other direction includes adopting rules to "establish proposed limitations." 25 The INDFW also compiles a decennial State Wildlife Action Plan (SWAP), but it expressly states that SWAP is simply "an overview of conservation threats in Indiana [that] identifies needed actions." 126

NESCA defines "take" in Indiana as to "harass, hunt, capture, or kill" wildlife

113. Nongame \& Endangered Wildlife, IND. DEP'T NAT. RES., https://www.in.gov/dnr/ fishwild/2356.htm (last visited Nov. 2, 2019) [https://perma.cc/GQ5D-FWT2].

114. Id.

115. IND. CODE § 14-22-34-1 (2019).

116. Id.

117. Id. § 14-22-34-13.

118. See Fischman et al., Species Legislation, supra note 1, at 98-101.

119. Indiana Endangered Species, supra note 15.

120. IND. CODE $§ 14-22-34-7$.

121. Id. $\S \S 14-22-34-7(\mathrm{~b})(2),-10$.

122. Id. § 14-22-34-11.

123. Id. § 14-22-34-3.

124. Id. § 14-22-34-14(a).

125. Id. § 14-22-34-8.

126. State Wildlife Action Plan - Habitat, Ind. DeP'T NAT. Res., https://www.in. gov/dnr/fishwild/7599.htm (last visited Nov. 18, 2020) [https://perma.cc/5E4R-QC5G]; see also Indiana State Wildlife Action Plan, IND. DEP'T NAT. RES. (2015), https://www.in.gov/dnr/ fishwild/files/fw-SWAP_2015.pdf [https://perma.cc/4DPS-L4V4]. 
or attempt to do so. ${ }^{127}$ Furthermore, a person may not "take, possess, transport, export, process, sell, or offer for sale or shipment" a species identified for management. ${ }^{128}$ This is the extent of the statutory take provisions. Some actions against endangered species in Indiana are allowed with appropriate permits: "removal, capture, or destruction of [endangered] species" is allowed under certain circumstances, such as to alleviate damage to property. ${ }^{129}$ Endangered species can only be affected as such without a permit when human life is immediately threatened. ${ }^{130}$

Several other statutes protect endangered species elsewhere in the Indiana Code. Outside of NESCA, the state asserts public ownership of wild animals and charges the INDFW with their protection and proper management. ${ }^{131}$ The state can use endangered status when determining whether to acquire land for nature preserves $^{132}$ or state waters. ${ }^{133}$ Coal mining and exploration is limited by consideration of endangered species. ${ }^{134}$ Causing pollution that harms an endangered species can constitute a felony. ${ }^{135}$ Finally, Indiana also protects habitat information for species by making sensitive locational information confidential. $^{136}$

\section{B. Key Gaps that Exist in the Absence of Federal Protection}

Even a cursory examination reveals the disparity in both the depth and amount of legislation between the ESA and NESCA. This is not unique to Indiana, but rather a common theme amongst the states. ${ }^{137}$ Legislative reform is needed to "implement stronger cooperative federalism under the ESA." 138 In congressional hearings, the intent of Congress for states to "play a greater role in preventing extinctions" is clear. ${ }^{139}$ A common theory proposes that states can more effectively implement endangered species recovery than the $\mathrm{ESA}^{140}$; Indiana needs to address legislative gaps to prove the merits of this theory supported by Congressional intent.

127. IND. CODE $\S 14-22-34-5$.

128. Id. § 14-22-34-9(1).

129. Id. $\S 14-22-34-16(\mathrm{c})$.

130. Id. § 14-22-34-16(b).

131. Id. $\S 14-22-1-1$.

132. Id. $\S 14-31-2-13(2)$.

133. See id. $\S 13-18-3-2$.

134. Id. $\S \S 14-34-4-7(\mathrm{a})(9), 14-34-9-6(2), 14-34-3-14(1)$.

135. Id. $\S 13-30-10-5(\mathrm{a})(2)(\mathrm{D})$.

136. Id. § 14-9-2-5(b).

137. See Fischman et al., Species Legislation, supra note 1, at 81; see also Camacho et al., supra note 21 , at 10843 .

138. Fischman et al., Species Legislation, supra note 1, at 82.

139. Id.

140. Id. at 81; see also Temple Stoellinger, Wildlife Issues Are Local - So Why Isn't ESA Implementation?, 44 ECOLOGY L.Q. 681, 712 (2017); Totoiu, supra note 2, at 10327. 
There are five key gaps in Indiana's NESCA that fall short of the more comprehensive protection found in the ESA. The first major gap is that there is no "threatened" status in NESCA as found in the ESA. ${ }^{141}$ Indiana can list species as endangered to receive protection and management, but separate "special concern" species receive no legal protection. ${ }^{142}$ Indiana's definition of "endangered" combines the ESA language for both endangered and threatened, thereby setting one statutory standard for both listing categories. ${ }^{143}$ Thus, whereas Indiana recognizes and protects both endangered and threatened ESA species, the INDFW does not recognize a threatened status for NESCA. ${ }^{144}$ Listing authority "must be dynamic to reflect the changes" in endangered species recovery and adapt accordingly. ${ }^{145}$ Having multiple tiers of protections allows protection to be extended to more species and earlier management when such species are in the early stages of decline. ${ }^{146}$ Thus, Indiana currently has no legislation that permits a second tier of protection to intervene in earlier stages of endangerment.

The second gap regards recovery plans as found in the ESA. Recovery planning authority in Indiana is limited or effectively non-existent. ${ }^{147}$ It is not mandated by statute. ${ }^{148}$ Although recovery planning under the ESA is often regarded as ineffective, federal agencies at least have the statutory grounds to implement recovery planning. ${ }^{149}$ NESCA does not require the INDFW to prepare recovery plans for species on its list; therefore, Indiana species rely on federal recovery plans. ${ }^{150}$ Indiana's SWAP specifically limits itself to recommendations and is not a plan of action ${ }^{151}$; therefore, Indiana lacks this fundamental statutory authority. ${ }^{152}$

The third gap relates to the protection of endangered species habitat, notably the required designation of "critical habitat" in the ESA. There is no habitat protection provision for listed species in Indiana. ${ }^{153}$ Incidental habitat modification is also not clearly prohibited. ${ }^{154}$ Indiana is not among the (only) five states that join the ESA by considering "significant modification of habitat . . . to be a form of prohibited take." 155 As "habitat loss and fragmentation are the greatest threats" to endangered species, adequate protective measures must exist

141. Indiana Endangered Species, supra note 15.

142. Id.

143. IND. CoDE $§ 14-22-34-1$ (2019).

144. Indiana Endangered Species, supra note 15.

145. Fischman et al., Species Legislation, supra note 1, at 103.

146. Totoiu, supra note 2, at 10317.

147. Camacho et al., supra note 21, at 10842.

148. Fischman et al., Species Legislation, supra note 1, at 99.

149. Totoiu, supra note 2, at 10308.

150. Fischman et al., Species Legislation, supra note 1, at 104.

151. Indiana State Wildlife Action Plan, supra note 126.

152. See Totoiu, supra note 2, at 10311.

153. Fischman et al., Species Legislation, supra note 1, at 99.

154. Id. at 110 .

155. Camacho et al., supra note 21 , at 10841. 
to properly aid recovery. ${ }^{156}$

The fourth significant gap is the requirement of interagency consultation. There is no Indiana statutory requirement for interagency consultation regarding actions that might harm endangered species. ${ }^{157}$ In the ESA, the interagency consultation requirement "ensures that any potential effects on a listed species from an activity proposed by a government agency are analyzed and minimized ...."158 This is particularly significant for protecting habitats from disturbance and degradation. ${ }^{159}$ Most importantly, consultation provides a united front amongst state agencies, "so that the recovery plans and critical habitat designations actually mean something" and can be implemented without conflicting governmental interests. ${ }^{160}$ By contrast, NESCA does not require interagency cooperation, but directs the Governor of Indiana to "[e]ncourage other state and federal agencies to use their authorities to further the purposes of this chapter." 161

The fifth and final significant gap relates to "take" prohibitions when compared to the ESA's notably strong "take" prohibitions (or the "teeth" of the ESA, as discussed supra Section I.A.2). Indiana's definition of "take" means only to "harass, hunt, capture, or kill" or attempt to do so. ${ }^{162}$ Significantly, it does not include "harm"; some states and the ESA define "harm" and include incidental harm through lawful activity. ${ }^{163}$ NESCA does not include lesser acts such as "disturbing," nor does it include authorization for enforcing permits for incidental taking. ${ }^{164}$ Permits are limited to specific circumstances, typically when endangered species are directly inflicting harm on persons or property. ${ }^{165}$ Ambiguous terms like "harass" or "harm," without express statutory definitions, do not indicate "whether the state legislation actually sustains the same regulatory or judicial interpretation as the ESA." ${ }^{166}$ Most importantly, this limited definition of "take" cannot protect habitat destruction or modification, which is the leading cause of species decline. ${ }^{167}$

\section{Analyzing the Impact of the August 2019 Changes on Indiana}

The existence of gaps in Indiana legislation for endangered species protection suggests that Indiana cannot implement such protection as effectively as intended.

156. Totoiu, supra note 2, at 10313.

157. Fischman et al., Species Legislation, supra note 1, at 107.

158. Camacho et al., supra note 21, at 10839.

159. Fischman et al., Species Legislation, supra note 1, at 106.

160. Totoiu, supra note 2, at 10313.

161. IND. CODE $§ 14-22-34-14$ (2019).

162. Id. $\S 14-22-34-5$.

163. Fischman et al., Species Legislation, supra note 1, at 110-14.

164. Id. at $110,113-16$.

165. IND. CODE $§ 14-22-34-16$.

166. Fischman et al., Species Legislation, supra note 1, at 114.

167. Totoiu, supra note 2, at 10301, 10311. 
If Indiana relies on federal ESA protection and legislation, then a lessening or weakening of the ESA will potentially compound problems with state implementation. ${ }^{168}$ The August changes to the administration of the ESA by the FWS therefore have the potential to impact Indiana's endangered species protection. A recent survey suggests that states do not believe they are seen as partners in ESA implementation by federal agencies. ${ }^{169}$ After discussing the possible impact of the August changes, analysis thereafter will propose how Indiana can address its own legislation to attempt to counteract any loss of federal protection.

There are three significant impacts on Indiana caused by the FWS rules changes. First, any changes to listings and threatened status protections affects Indiana's statutory protection of federally listed species. ${ }^{170}$ State protections afforded by state listings are meant to cover species not protected by the ESA. ${ }^{171}$ Indiana generally protects species on the ESA lists; once species are removed from federal protection, Indiana will have to make its own determinations for whether to place them on Indiana's list. State protection is expected to "rise above the floor established by the federal government."172 Without a threatened status, relaxed federal protection of threatened species invites potential harm to Indiana species that are unlisted by NESCA. ${ }^{173}$

Second, without required state interagency consultation, Indiana necessarily relies on federal interagency consultation. ${ }^{174}$ With relaxed federal standards, Indiana's gap with federal protection could therefore widen. Interagency consultation is essential to effective recovery plans and critical habitat designation. ${ }^{175}$ It is necessary to slow down "ill-considered projects" and investigate environmental impact. ${ }^{176}$ If Indiana is no longer assured the same level of cooperation amongst federal agencies, then it may need more statutory authority in place to mitigate this effect. ${ }^{177}$

Finally, and perhaps most importantly, since a majority of state laws rely on the ESA, conservation and recovery in states will be undermined by "devolution of federal authority." ${ }^{178}$ Congressional hearings on the ESA are consistent, however, in urging that "states should play a greater role in preventing extinctions." ${ }^{179}$ Therefore, in a general sense, any changes to the ESA or its federal implementation necessarily impact the protection and management of

168. See Fischman et al., Species Legislation, supra note 1, at 123-24.

169. Stoellinger, supra note 140 , at 712.

170. See IND. CODE $§ 14-22-34-1$; but see id. § 14-22-34-13.

171. Totoiu, supra note 2, at 10317.

172. Fischman, Predictions and Prescriptions, supra note 31, at 461.

173. See Totoiu, supra note 2, at 10311.

174. See InD. CODE $§ 14-22-34-14$.

175. Totoiu, supra note 2, at 10313.

176. Fischman, Predictions and Prescriptions, supra note 31, at 456.

177. See generally Fischman et al., Species Legislation, supra note 1, at 81.

178. Camacho et al., supra note 21, at 10843.

179. Fischman et al., Species Legislation, supra note 1, at 82. 
species in Indiana. Furthermore, Congress has always and will continue to expect the states to step up their legislative and administrative efforts. ${ }^{180}$ Overall, the FWS changes suggest several potential effects on NESCA that reveal gaps between state and federal endangered species protections.

\section{How to RESOlve THE GAPS BETWEEN INDIANA AND FEDERAL PROTECTION}

Indiana is not alone amongst the states regarding its weak endangered species legislation. Most states fall short of the comprehensive protection envisioned by the ESA. ${ }^{181}$ This section will discuss the common weaknesses amongst state endangered species legislation, then highlight a three-pronged aggregate of Indiana's greatest weakness. A proposed solution will follow, analyzing common recommendations to address such weaknesses while incorporating what more protective states have done to align more closely with the ESA. Finally, recommendations for further investigation and suggested political implications of such legislation will round out the discussion.

According to ESA scholar Robert Fischman, if we are in fact facing a devolution of federal control over endangered species through the weakening of the ESA, then "state legislative reform will need to precede greater devolution of federal authority ...."182 States are in a unique position to have greater success in protecting endangered species: "By virtue of their constitutional powers, their expertise, and their on-the-ground personnel, states could-in theory-accomplish far more than the federal agencies directly responsible for implementing the Endangered Species Act (ESA)." ${ }^{\prime 83}$ Now is the time for Indiana's legislature to align itself with the original intent of the ESA and take greater control of endangered species protection at the state level. ${ }^{184}$ Although not as successful as some originally hoped, the ESA still plays a critical role in endangered species recovery. ${ }^{185}$ Indiana can further this effort by strengthening NESCA.

\section{A. Common Weaknesses Amongst State Endangered Species Protection}

Various surveys have shown that states are generally more permissive and fall short of the ESA: they fail to prohibit habitat impairment, to provide mechanisms for recovery, to minimize incidental harms, and to "restrict state agency actions that undermine species recovery." legislation - considered as an aggregate - is "weaker than the ESA, "lacking in

180. See Totoiu, supra note 2, at 10304.

181. Id.

182. Fischman et al., Species Legislation, supra note 1, at 117.

183. Id. at 81 .

184. Fischman, Predictions and Prescriptions, supra note 31, at 463.

185. Totoiu, supra note 2, at 10327.

186. Id. at 10304; Fischman et al., Species Legislation, supra note 1, at 81; see also Camacho et al., supra note 21 , at 10837. 
regulatory teeth and policy innovation." "187 Overall, state legislation is nowhere near as comprehensive. ${ }^{188}$

Habitat protection is a critical common weakness. Thirty-eight states "fail to provide any authority for the designation of critical habitat for listed species."189 Only five states align with the ESA by defining significant modification of habitat as a prohibited take. ${ }^{190}$ This is especially concerning because "nearly $80 \%$ of endangered species have relied on private lands for all or some of their habitat."191 Typically, economic development on private land causes this modification of critical habitat ${ }^{192}$; without meaningful habitat protection, species are put at great risk. ${ }^{193}$ There are only thirteen states that could be said to prohibit this incidental take of habitat modification; yet even those statutes would be subject to interpretation. ${ }^{194}$

Another common weakness amongst the states is interagency consultation. Only twelve states "have any consultation requirement in their state ESA law."195 The ESA compels federal agencies to consult with the Secretary of the Interior to ensure its actions do not further endanger species or adversely modify critical habitat. ${ }^{196}$ This requirement seeks to limit potential effects on listed species by "partner[ing] with those officials in that jurisdiction with the experience, training, and expertise in endangered species management." 197

Although there are common weaknesses amongst the majority of states, not all fall short of the ESA: "[t]hough current state laws, in aggregate, would not adequately replace the operative provisions of the ESA under cooperative federalism, some state provisions are very strong." 198 Some states even surpass the ESA. 199 "Cooperative federalism" was envisioned by Congress when the Act was passed in $1973 .{ }^{200}$ It refers to cooperation and reciprocal support between the ESA and state endangered species protection. ${ }^{201}$ More specifically, "[c]ooperative federalism creates a set of minimum national standards [for the states to follow] that the federal government will implement, [but only] if necessary." ${ }^{202}$ Congress

187. Fischman et al., Species Legislation, supra note 1, at 116.

188. Totoiu, supra note 2, at 10304.

189. Camacho et al., supra note 21, at 10840.

190. Id. at 10841 .

191. Id.

192. Fischman et al., Species Legislation, supra note 1, at 112.

193. See Totoiu, supra note 2, at 10301.

194. Fischman et al., Species Legislation, supra note 1, at 114.

195. Camacho et al., supra note 21, at 10839.

196. $I d$.

197. Id.

198. Fischman et al., Species Legislation, supra note 1, at 117 (emphasis in original).

199. Totoiu, supra note 2, at 10304; see also Fischman et al., Species Legislation, supra note 1 , at 81 .

200. Fischman, Predictions and Prescriptions, supra note 31 , at 461.

201. Id.

202. Id. 
originally intended for states to "play a large role in implementing the ESA," and this concept remains increasingly important to the effective implementation of endangered species recovery. ${ }^{203}$

\section{B. Indiana's Greatest Weakness in Endangered Species Protection}

As shown in the examination of NESCA and the ESA, Indiana's level of endangered species protection ranks, at best, in the bottom half of the states. ${ }^{204}$ Indiana shares in many of the common weaknesses amongst states and has several glaring gaps that are not as common. ${ }^{205}$ No single greatest weakness exists; instead, a three-pronged aggregate of basic protection is needed with a focus on "recovery planning." The "primary goal of the federal ESA is to recover species" so they no longer require protection and may be delisted. ${ }^{206}$ Furthermore, there are species in Indiana that may need protection and management and will not likely receive such protection by the federal government. ${ }^{207}$ Indiana needs to round out its basic legislative protection to approach the floor provided by the ESA. ${ }^{208}$ Once that floor is met, or close to it, only then can Indiana examine how to strengthen protections to assume its greater role envisioned by Congress in $1973 .^{209}$

This three-pronged proposal focuses on the need for: (1) threatened status; (2) habitat protection; and (3) recovery planning. The proposal is not nearly as aggressive as it could be but considers a modest increase in legislation. This is due in part to the low likelihood of enacting a large increase in statutory protection in one fell swoop. Instead, this proposal is incremental-albeit a substantial first installment - and should be built upon in the future after review and determinations of efficacy.

The first prong focuses on the need for a separate "threatened" status in NESCA. Currently, NESCA only provides for an "endangered" listing or the "special concern" listing that affords no legal protection under NESCA. ${ }^{210}$ The ESA addressed the criticisms of prior federal endangered species legislation and created a "threatened" status so that agencies could act sooner to "preserve species before they became endangered . . . ."211 By offering two listing categories, Indiana can diversify its response to species endangerment; this will also diversify the other prongs below of recovery planning and habitat protection.

The second prong proposes increased statutory protection for endangered species habitats. Habitat protection is critical to effective endangered species

\footnotetext{
203. Id. at 463.

204. Cf. Fischman et al., Species Legislation, supra note 1, at 98-116.

205. Cf. id.

206. Camacho et al., supra note 21, at 10842.

207. Cf. Totoiu, supra note 2, at 10317.

208. See Fischman, Predictions and Prescriptions, supra note 31, at 461-63.

209. Totoiu, supra note 2, at 10304.

210. Indiana Endangered Species, supra note 15.

211. Kaile, supra note 23, at 454.
} 
legislation, as "[t]he single greatest cause of species decline into imperiled status is habitat modification or destruction." ${ }^{212}$ There is much potential for states to have greater control in land management. ${ }^{213}$ Furthermore, without meaningful legislation to protect habitats, Indiana's recovery plans (the third prong) would be largely meaningless and actual recovery of species likely unattainable. ${ }^{214}$ This is another glaring weakness common amongst states, as "only Massachusetts expressly recognizes habitat destruction as a prohibited 'take' of a species."215 Redefining "take" in Indiana and providing stricter legislation to protect habitats will go a long way toward better protection aligned with the ESA, and such legislation can be passed without substantially impinging on the rights of private landowners. ${ }^{216}$

The third prong focuses on the need for statutory requirements for recovery plans. To focus on recovery planning - the ultimate goal of this proposal-Indiana needs actual legislation that requires recovery planning. The current SWAP is simply "an overview of conservation threats in Indiana [that] identifies needed actions." ${ }^{" 17}$ Few states have any experience with establishing or affecting any recovery planning through administrative regulation, and only three states require recovery plans for listed species. ${ }^{218}$ This is a glaring weakness common amongst states and is critical to actualizing the intent of the ESA, which is sufficient population recovery that leads to effective delisting. ${ }^{219}$ The other common issue with recovery plans is they are often hollow and unenforceable. ${ }^{220}$ To be successful, Indiana needs recovery plans for listed species that are specific and have mandatory measures, strict timelines, and mechanisms to enforce them. ${ }^{221}$ Such plans can account for whether a species is endangered or only threatened and assign resources accordingly.

\section{Proposed Solution for Indiana}

This three-prong proposal addresses the three largest gaps and calls for legislative action to fill them. Rather than focusing on a complete overhaul of one facet of NESCA, this proposal finds that Indiana should round out protection to provide at least a minimal reflection of the comprehensive protection of the ESA. This will establish a first step toward filling the gaps that will exist if further devolution of the ESA's implementation occurs. In analyzing the common weaknesses of most state acts and the relative strengths of a few, this proposal

212. Fischman et al., Species Legislation, supra note 1, at 121.

213. Totoiu, supra note 2, at 10310.

214. See id. at 10313.

215. Fors, supra note 5, at 184.

216. Totoiu, supra note 2, at 10325-26.

217. Indiana State Wildlife Action Plan, supra note 126.

218. Fischman et al., Species Legislation, supra note 1, at 104.

219. Davison, supra note 57, at 542.

220. Totoiu, supra note 2, at 10308.

221. Id. 
finds that three facets of NESCA should be addressed for complete protection: (1) multiple listing categories; (2) express statutory authority for habitat protection; and (3) recovery planning authority.

1. Expand Listing Status Categories with Tapered Protection.-States like Florida, or particularly the federal ESA, show that endangered species legislation with multiple listing categories is feasible. ${ }^{222}$ Allowing some protections for threatened or special concern species might slow the advance to full endangered status. ${ }^{223}$ Therefore, creating a default threatened status could give Indiana direct control over the early stages of decline, shifting the ESA to focus on species threatened with imminent extinction. ${ }^{224}$

As discussed supra Section I.A.1, the ESA has two listings of endangered and threatened. "Threatened" is a separate category that purports to expand ESA protection to account for species that are "likely to become an endangered species within the foreseeable future." ${ }^{25}$ In doing so, the ESA effectively broadens its coverage and protections that can go into place before species recovery is further harmed. ${ }^{226}$ The difference in listing categories typically relates to "acceptable risks of species extinction" which are "social policy decisions" informed by science. ${ }^{227}$ The difficulty of predicting events such as endangerment and extinction are problematic, however, and the decisions end up being the "educated guesses" of experts. ${ }^{228}$ Regardless, adding another category will allow action at an earlier point to maintain levels of "acceptable risk" in each species. ${ }^{229}$

Indiana currently has two listings of "endangered" and the "special concern status" (which includes no legal protection). ${ }^{230}$ Indiana's current definition of "endangered" species, however, includes the same language as the ESA's "threatened" listing ${ }^{231}$ : "likely to become an endangered species within the foreseeable future." ${ }^{232}$ Indiana should add legislation that diversifies NESCA's current definition of "endangered" to also create a default listing of "threatened" that tracks species decline earlier and offers "primary authority over conservation and recovery." 233 This could "motivate on-the-ground state conservation action in order to stave off the threat of increased federal involvement if the species continues to decline," 234 thus relieving some of the pressure on the ESA and ensuring Indiana's involvement in the absence of federal protection. Furthermore,

222. Id. at 10310-11.

223. Id. at 10311 .

224. Stoellinger, supra note 140 , at 720 .

225. 16 U.S.C.A. $§ 1532(20)$ (West 2019); see also Totoiu, supra note 2, at 10302.

226. See Totoiu, supra note 2, at 10311.

227. Doremus, supra note 26, at 1117.

228. Id. at 1121.

229. See id. at 1117; see also Totoiu, supra note 2, at 10317.

230. Indiana Endangered Species, supra note 15.

231. Ind. CODE $\S 14-22-34-1$ (2019).

232. 16 U.S.C.A. $\S 1532(20)$ (West 2019).

233. Stoellinger, supra note 140 , at 720 .

234. Id. at $720-21$. 
it is well-established and often urged that "[p]reserving ecosystems and protecting against habitat loss and degradation is critical to the recovery of listed species." 235 By adding a "threatened" listing, Indiana could force early involvement to begin managing habitats before the species has declined into "endangered" status and before the federal protection (or lack thereof) is relied upon by Indiana agencies. ${ }^{236}$

"The cornerstone of the ESA is the listing provision."237 Part of the concern regarding the reduction of threatened species protection in the ESA was the fact that having two listing categories with the same level of protection was inefficient. ${ }^{238}$ Adding a statutory threatened category could offer some level of protection to more species with less exacting stringency than the endangered category, providing more protection without demanding as much to maintain flexibility. ${ }^{239}$ A new listing category need not mirror the protections provided by NESCA for endangered species, but provide the statutory means for the INDFW to determine how to best implement habitat protections and begin the recovery planning (see discussion infra Sections III.C.2, III.C.3) before a species reaches the critical endangered threshold. ${ }^{240}$ Another possibility would be to fold "threatened" into the existing "special concern" status and provide statutory authority to extend some protection to "special concern" species. Regardless, the new listing category should be included in "take" prohibitions to halt active endangerment of the threatened species. ${ }^{241}$

2. Express Statutory Authority for Habitat Protection.-As discussed in Sections I.A.3 and III.A, habitat protection is critical to effective endangered species legislation as habitat modification or destruction is a leading cause of species decline. ${ }^{242}$ State acts, like NESCA, have the potential to protect important habitats beyond the effective reach of the ESA. ${ }^{243}$ As Indiana does not currently address habitat modification - adverse or otherwise - as a form of "take," statutory authority is needed to protect critical habitats. ${ }^{244}$

Habitat protection would not need to duplicate existing federal critical habitat protection; however, less than half of the species listed under the ESA have protected habitats. ${ }^{245}$ Furthermore, the concept of "critical habitat" is not fully realized in NESCA. ${ }^{246}$ The statutory directive is rather vague and appears discretionary: the director of the INDFW "shall establish the programs, including

235. Totoiu, supra note 2, at 10309.

236. Fischman et al., Species Legislation, supra note 1, at 122.

237. Totoiu, supra note 2, at 10310.

238. See Wood, supra note 89.

239. Fischman et al., Species Legislation, supra note 1, at 92.

240. See Doremus, supra note 26, at 1049-50.

241. See Totoiu, supra note 2, at 10311.

242. Fischman et al., Species Legislation, supra note 1, at 121.

243. Totoiu, supra note 2, at 10313.

244. Id.

245. $I d$.

246. See IND. CodE $\S \S 14-22-34-1$ to -21 (2019). 
acquisition of land or aquatic habitat, that are considered necessary for the management of nongame species." ${ }^{247}$ Also, the Indiana Department of Natural Resources may acquire "natural areas" that are considered habitat for endangered species. ${ }^{248}$ In contrast, the ESA requires the FWS to designate critical habitat upon listing the species as endangered or threatened. ${ }^{249}$ At a minimum, Indiana should add legislation requiring the designation of critical habitat for listed species (both endangered and the proposed new listing of threatened) that "include[s] specific areas occupied by the species at the time of listing with features 'essential' to the conservation of the species." ${ }^{250}$

Indiana does not emulate the ESA by considering "significant modification of habitat . . . to be a form of prohibited take." 251 The current definition of "take" in NESCA prohibits enumerated actions against protected species: actions include to harass, hunt, capture, kill, or attempt to do any of these. ${ }^{252}$ Designating critical habitat is a hollow gesture without statutory protection against actions that significantly modify such habitat ${ }^{253}$; otherwise, there is no defense against this greatest cause of species decline. Redefining "take" in Indiana and providing stricter legislation to protect habitat will go a long way toward better protection aligned with the ESA, and such legislation need not substantially impinge on the rights of private landowners. ${ }^{254}$

Some states included "harm" in their statutory definition of "take" and left it to the relevant agency to interpret "harm" as significant habitat modification. ${ }^{255}$ Though this might provide at least a minimum, Indiana could instead look to a Massachusetts statute which "declares that "no person may alter significant habitat" and likens this significant habitat to the ESA's concept of critical habitat. $^{256}$ At the very least, Indiana should amend NESCA to include a designation of critical habitat with each listing, which will, at a minimum, provide statutory weight for protecting such habitat as necessary to slow species decline.

3. Recovery Planning Authority with Requirements and Expectations.-The ESA mandates the development and implementation of recovery plans toward the "conservation and survival" of listed species. ${ }^{257}$ The word "recovery" is not present in the entirety of NESCA ${ }^{258}$; the INDFW is required to establish

247. See id. § 14-22-34-14 (requiring only those programs considered "necessary," which seems to allow INDFW full latitude to define "necessary").

248. Id. § 14-31-2-13.

249. 16 U.S.C.A $\S 1533(\mathrm{a})(3)(\mathrm{A})$ (West 2019); see also Totoiu, supra note 2, at 10302.

250. Totoiu, supra note 2, at 10302.

251. Camacho et al., supra note 21, at 10841.

252. IND. CODE $\S 14-22-34-5$.

253. See Totoiu, supra note 2, at 10313.

254. Id. at 10325-26.

255. Fischman et al., Species Legislation, supra note 1, at 112-13.

256. Id. at 113 .

257. 16 U.S.C.A $\S 1533(\mathrm{f})(1)$ (West 2019).

258. See IND. CodE $\S \S 14-22-34-1$ to -21 (2019). 
"programs . . . considered necessary for the management of nongame species."259 Across the nation, only a handful of states require more detailed recovery planning. ${ }^{260}$ Successful ESA recovery planning requires specific management actions, observable and measurable criteria, and estimates of time and cost. ${ }^{261}$ To effectuate the true intent of endangered species legislation, Indiana must add statutory authority and requirements to create recovery plans for species. ${ }^{262}$

Four states combine "procedural and substantive requirements" for recovery plans and "go beyond the ESA" in developing actual programs for recovery. ${ }^{263}$ Indiana, like most states, produces a SWAP; however, SWAP is not an operational plan. ${ }^{264}$ To effect true recovery planning for endangered (and the newly proposed threatened) species, Indiana will have to add legislation to NESCA. Recovery plans set benchmarks to track a species' progress towards recovery. ${ }^{265}$ Without diving into the details of the topic, well beyond the scope of this analysis, examples from a few states' statutory codes are provided:

New Mexico Statutes Annotated § 17-2-40.1(E)

$[\mathrm{T}]$ he director shall develop a draft recovery plan to achieve the following objectives:

(1) restoration and maintenance of a viable population of the threatened or endangered species and its habitat reasonably expected to lead to the delisting of the species;

(2) avoidance or mitigation of adverse social or economic impacts;

(3) identification of social or economic benefits and opportunities; and

(4) use of volunteer resources and existing economic recovery and assistance programs and funding available from public and private sources to implement the plan. ${ }^{266}$

\section{Oregon Revised Statutes $§$ 496.182(2)(a)}

At the time the State Fish and Wildlife Commission adds a species to the list of threatened species or endangered species under ORS 496.172, the commission shall establish by rule quantifiable and measurable guidelines that it considers necessary to ensure the survival of individual members of the species. ${ }^{267}$

259. Id. § 14-22-34-14(a).

260. Fischman et al., Species Legislation, supra note 1, at 117.

261. 16 U.S.C.A. § 1533(f)(1); see also Totoiu, supra note 2, at 10302.

262. See Totoiu, supra note 2, at 10311.

263. Fischman et al., Species Legislation, supra note 1, at 117.

264. See Indiana State Wildlife Action Plan, supra note 126.

265. Fischman et al., Species Legislation, supra note 1, at 104.

266. N.M. STAT. ANN. § 17-2-40.1(E) (West 2019).

267. Or. Rev. StAT. AnN. $§ 496.182(2)$ (a) (West 2019). 


\section{General Statutes of North Carolina § 113-333(a)}

In the administration of this Article, the Wildlife Resources Commission shall have the following powers and duties:

(3) To coordinate development and implementation of conservation programs and plans for endangered and threatened species of wild animals and for species of special concern.

(4) To adopt and implement conservation programs for endangered, threatened, and special concern species and to limit, regulate, or prevent the taking, collection, or sale of protected animals. ${ }^{268}$

As shown, a significant difference between these examples and NESCA is the specificity of language. NESCA only requires the establishment of programs considered necessary for management. ${ }^{269}$ It requires a consideration of recovery plans, not a requirement for such plans. This proposal would have Indiana expressly require the development of recovery plans for its endangered (and threatened) species.

Recovery plans should focus on habitat preservation, which incorporates both recovery planning and habitat protection ${ }^{270}$; this further incorporates the second prong of the proposal discussed above. Indiana can further expand the existing critical habitat designations of the ESA in its recovery plans, as states are positioned to more effectively manage such land, ${ }^{271}$ in addition to providing the aforementioned critical habitat designations and corresponding recovery plans for its state-listed species. States maintain existing relationships with private landowners and can more effectively create recovery plans on both public and private land ${ }^{272}$; therefore, Indiana may be better poised to drive recovery through these plans.

Indiana has already provided the INDFW with the statutory authority to acquire land for endangered species management. ${ }^{273}$ The next step would be to require formal recovery plans that require the acquisition of such land or its protection for each species, tailored to and driven toward the goal of recovery of that species.

4. Why Legislation is Preferred.-Strengthening any one of these (listing categories, habitat protection, recovery planning) while the others remain nonexistent is far less likely to succeed. ${ }^{274}$ Without stronger take definitions and multiple listing categories, other protections may be too late to have a positive effect on recovery. ${ }^{275}$ Without habitat protection, recovery cannot be implemented

268. N.C. Gen. StAT. AnN. § 113-333(a) (West 2019).

269. IND. CODE § 14-22-34-14(a) (2019).

270. Totoiu, supra note 2, at 10312.

271. See id. at 10313.

272. Stoellinger, supra note 140 , at 716 .

273. IND. CODE $§ 14-22-34-14$.

274. See Totoiu, supra note 2 , at 10310.

275. See id. at 10317-18; cf. Stoellinger, supra note 140, at 720 ("threatened" status invokes 
and cannot achieve success. ${ }^{276}$ Without recovery planning, the purpose of saving endangered species is not met. ${ }^{277}$ Even shallow or minimal statutory authority — so long as all three prongs are realized - should be preferred rather than focusing on one facet and ignoring others.

Legislative action will be the most effective first step as it serves as a foundation for a more complete NESCA that addresses all necessary facets of successful endangered species protection at least minimally. ${ }^{278}$ There are benefits to focusing on statutory detail rather than administrative discretion, as "statutory detail can provide good political cover for agency officials too weak to make good decisions on their own." ${ }^{279}$ Weaker state laws that rely on federal regulation tend to undermine species recovery. ${ }^{280}$ Florida's endangered species legislation provides an excellent example, and it is suggested that "weak statutory powers" become "potentially more vulnerable to political shifts in administrative appointments to the commission." 281 Statutory detail therefore may help prevent vulnerabilities in effective administration of NESCA.

The ESA is a "hybrid of resource management and pollution control," making it an adaptive, modern environmental act. ${ }^{282}$ To perform well, however, improved state laws are needed to relieve pressure on federal FWS implementation and improve endangered species protection across Indiana. ${ }^{283}$ There are four states that already improved their legislation and provide excellent models: Illinois, Massachusetts, Oregon, and Wisconsin. ${ }^{284}$ As it stands, without significant Indiana law reforms, the "devolution of federal authority" has the potential to "undermine conservation and recovery efforts, lead to a greater number of species becoming imperiled, and result in fewer species recovered." 285

\section{Recommendations for Further Endangered Species Protection}

Funding is critical for successful endangered species management, particularly habitat protection. ${ }^{286}$ Recent studies show that state funding accounts for only $5 \%$ of total ESA spending. ${ }^{287}$ Cooperative federalism shows a potential

state authority).

276. See Totoiu, supra note 2, at 10301.

277. See id. at 10300.

278. See id. at 10317-18; see also Fischman et al., Species Legislation, supra note 1, at 118-19; Camacho et al., supra note 21, at 10843.

279. Robert L. Fischman, The Divides of Environmental Law and the Problem of Harm in the Endangered Species Act, 83 IND. L.J. 661, 681 (2008).

280. Camacho et al., supra note 21, at 10843.

281. Fischman et al., Species Legislation, supra note 1, at 120.

282. Fischman, Predictions and Prescriptions, supra note 31, at 465.

283. Fischman et al., Species Legislation, supra note 1, at 123.

284. Id. at 117.

285. Camacho et al., supra note 21, at 10843.

286. Fischman, Predictions and Prescriptions, supra note 31, at 474.

287. Camacho et al., supra note 21, at 10838. 
model to correct this issue by giving states more funding and authority while expecting stronger state programs. ${ }^{288}$ State laws provide local power over regulation and land use; under cooperative federalism, the federal government has opportunities to "strike bargains giving states a greater say over imperiled species regulation in exchange for more effective habitat protection and improvement."289 However, statutory reform is needed before any mere transfer of federal funding to Indiana can be effective. ${ }^{290}$ Once such reform is achieved, funding can be successfully transferred from federal agencies and will be needed to support significant reform. ${ }^{291}$

Interagency consultation is critical to effecting recovery plans, managing and measuring recovery, and ensuring united protection of endangered species. ${ }^{292}$ However, reform of interagency consultation would need to succeed the proposed changes for NESCA so that such cooperation can enforce more comprehensive endangered species laws; as such, interagency consultation is a necessary reform, but beyond the scope of this analysis. With any potential reform of NESCA, however, Indiana must examine the federal experience with endangered species law and "how the ESA has fallen short of achieving its overarching purpose of species recovery and ecosystem protection." ${ }^{293}$ States like Indiana must "develop mechanisms that prioritize the role of recovery and ecosystem protection in their endangered species protection laws. ${ }^{294}$ In other words, Indiana should ensure that its legislation is capable of authorizing the level and breadth of protection it envisions. It must also ensure that such legislation requires the requisite implementation and mandates self-evaluation of it.

\section{E. Political Implications of this Proposal}

Proposals for legislative reform might hearten those in favor of protecting endangered species, but the political implications of such proposed reform cannot be ignored. Although such a topic is well beyond the scope of this analysis, a few trends common to other states can be noted. First, any expansion or strengthening of current law-particularly with habitat protection-will encounter private property owners who are unhappy about restrictions on land usage. ${ }^{295}$ It is well understood and expected that "[s]tate politicians do not wish to become targets for opposition from constituents who oppose constraints on private property development." ${ }^{296}$ Undecided state legislators may oppose any such reforms to protect habitat in order to avoid unhappy constituents or simply represent

288. Fischman et al., Species Legislation, supra note 1, at 118-19.

289. Id. at 121.

290. See id. at 118.

291. See id. at 124.

292. Totoiu, supra note 2, at 10313-14.

293. Id. at 10310.

294. Id.

295. Fischman et al., Species Legislation, supra note 1, at 121-22.

296. Id. 
constituent values. Second, there is common concern that "states are more susceptible to bending to political pressure from those who oppose unpopular species conservation decisions (as many species conservation decisions are unpopular). ${ }^{, 297}$ At the very least, enacting such substantial legislation (even if minimal by comparison to other states) could likely garner substantial opposition and would take concerted support within Indiana's voters and cooperation (if not sacrifice) from some of its legislators.

Obtaining federal support from a cooperative federalism standpoint (discussed in Section III.D) or even promises of increased funding may soften opposition to this proposal. In the past five years, however, the Indiana General Assembly has passed no relevant major laws concerning endangered species or habitat preservation, and no such bills remain active. ${ }^{298}$ One relevant resolution-Indiana Senate Resolution 61 - was proposed in 2014 and urged the "Legislative Council to assign to the appropriate study committee the topic of the feasibility and necessity of a wilderness preservation system for Indiana's public lands." ${ }^{299}$ The Senate Committee on Agriculture and Natural Resources (now split into separate committees) reported a recommendation to pass this resolution; however, it has not been discussed or reintroduced since, though it remains active. $^{300}$ In 2015, Senate Joint Resolution 2 was passed and became law. ${ }^{301}$ Public Law 258 became part of Indiana's Constitution and Bill of Rights, establishing, inter alia, "[t]he right to hunt, fish, and harvest wildlife" subject to Indiana laws that "promote wildlife conservation and management," and further establishing that "[h] unting and fishing shall be a preferred means of managing and controlling wildlife." ${ }^{\prime 32}$ The absence of other related proposals coupled with the juxtaposition of these proposed resolutions - and which one prompted swift action - is a limited but potentially provocative example of recent trends in state legislation regarding Indiana wildlife.

\section{F. Further Proposed Changes}

On July 31, 2020, the FWS announced further proposed changes to the administrative definition of critical habitat. ${ }^{303}$ While the FWS maintains these changes will "increase the clarity of the ESA, . . stimulate more effective

297. Stoellinger, supra note 140 , at 716.

298. See Bills for 2019 Session, IND. GEN. AsSEMB., http://iga.in.gov/legislative/2019/bills/ (last visited Dec. 27, 2019) [https://perma.cc/FC36-MVU6] (contains archives for each year).

299. S. Res. 61, 118th Gen. Assemb., 2d Reg. Sess. (Ind. 2014).

300. Ind. S. Comm. on Agric. \& NAt. Res., 118Th Gen. Assemb., Rep. on S. Res. 61 (Comm. Rep. 2014).

301. S.J. Res. 2, 119th Gen. Assemb., 1st Reg. Sess. (Ind. 2015).

302. Ind. CONST. art. $1, \S 39$.

303. Press Release, U.S. Fish and Wildlife Service and NOAA Fisheries Propose Regulatory Definition of Habitat Under Endangered Species Act, U.S. FiSH \& WiLDLIFE SERV. (July 31, 2020), https://www.fws.gov/news/ShowNews.cfm?ref=u.s.-fish-and-wildlife-service-and-noaa-fisheriespropose-regulatory-\&_ID=36747 [https://perma.cc/D9BN-BM9D]. 
conservation on the ground, and improve consistency and predictability around critical habitat determinations, ${ }^{, 304}$ law analysts and environmentalist groups again see possible threats to the success of the ESA. There is concern the proposed changes "may limit what areas may be designated as 'critical habitats' by excluding areas that could potentially support a threatened or endangered species, but currently do not." ${ }^{305}$ This provides another example of the drastic changes that might shift the amount of protection provided by the federal ESA. With a new presidential administration, more changes could be implemented over the next few years, which further amplifies the need to revisit and reevaluate NESCA.

\section{CONCLUSION}

The ESA was not designed or envisioned to bear the brunt of endangered species protection. ${ }^{306}$ It was meant to be a failsafe for the most critically endangered species, while states would take on the majority of protective duties. ${ }^{307}$ Indiana's statutory response, however, is an example of the gaps that exist despite congressional intent in 1973. If time proves that the recent changes in fact weakened the ESA, the gaps between state laws and federal laws may widen. Endangered species will be left with less protection than ever, with results that we can forecast but never fully predict.

The threat of weakened federal environmental protection in general should serve as an overdue wake-up call to Indiana and other states. ${ }^{308}$ In the current climate of heightened environmental awareness, it is imperative that states ensure their own environmental statutes confer the level of protection desired. If the current trend of relaxing federal protection of the environment continues, states will no longer be able to rely on federal statutes to fill these gaps. ${ }^{309}$ The time is ripe for Indiana and similarly situated state legislatures to evaluate their priorities.

Indiana, like most states, fails to match up to the level of protection envisioned by the ESA. ${ }^{310}$ States are positioned to lead the way in protecting endangered species and should take charge. ${ }^{311}$ As discussed, there are many critical gaps that fall outside of the scope of this analysis. Enacting new legislature to address the concept of recovery planning can tackle many of these critical gaps in a broad, if somewhat shallow, advance in protection. If Indiana can at least provide minimal, basic statutory authority for the three major gaps

304. Id.

305. Stephanie Amaru et al., Proposed Definition of "Habitat" May Endanger the Endangered Species Act, Pillsbury Winthrop Shaw Pittman LlP (Aug. 27, 2020), https://www. pillsburylaw.com/en/news-and-insights/proposed-definition-habitat-may-endanger-endangeredspecies-act.html [https://perma.cc/NXS3-8G8F].

306. Totoiu, supra note 2, at 10304.

307. See Stoellinger, supra note 140, at 725.

308. See Fischman et al., Species Legislation, supra note 1, at 123.

309. See id.

310. See id. at 116-17.

311. See id. at 81 . 
discussed, Indiana's administration will have the foundation of protection it lacks and a baseline from which to develop further in the most beneficial way.

A three-pronged approach to state recovery planning can help identify which areas of focus are the most effective and efficient: multiple listing statuses with comprehensive, responsive definitions of "take"; habitat protection that not only designates critical habitat but provides the means to safeguard it; or detailed, time-sensitive recovery plans that demand accountability and afford statutory authority. By providing first the rudimentary protections envisioned by these foci, Indiana's endangered species can gain comprehensive and whole, if minimal, protection. ${ }^{312}$ The hope would be that decline in species can slow when no longer falling through these gaps in protection. One might float further in a boat with many small leaks than three large holes.

This proposal would be merely a first step in a long process to overhaul Indiana's endangered species protection. Funding will be another major gap that the legislature can at least partially address, though outside of the scope of this Note. As the analysis suggests, however, Indiana's NESCA has holes that must be filled before Indiana can attain even a measure of the protection envisioned by the ESA. The three pillars of listing, habitat protection, and recovery planning must exist in some form to pretend at a successful endangered species act. The basic statutory protections proposed in this Note should provide that foundation from which to build a better NESCA for Indiana.

312. Cf. id. (avoiding the "more permissive attitude" that "only weakly support[s] cooperative federalism" by addressing the common failures in protection shared among the majority of states and gaining the "capacity to employ the key regulatory tools that prompt collaborative conservation"). 